\title{
MAIN INDIVIDUAL AND TYPOLOGICAL PARAMETERS OF HIGHER NERVOUS ACTIVITY IN YOUNG PEOPLE OF DIFFERENT SOMATOTYPE WITH NORMAL AND HIGH BLOOD PRESSURE
}

\author{
S.N. Vadzyuk, *L.I. Horban, I.Ya. Papinko \\ I. HORBACHEVSKY TERNOPIL NATIONAL MEDICAL UNIVERSITY, TERNOPIL, UKRAINE
}

Background. The individual and typological features of the central nervous system are interpreted as highly genetically determined. Each somatotype is characterized by morphofunctional features of the activity of different systems, including the circulatory system.

Objective. The aim of the research was to study the features of the main individual and typological parameters of higher nervous activity in persons of different somatotype with normal and high blood pressure (BP).

Methods. In the control group of the surveyed patients the BP value corresponded to the optimal level according to the WHO classification (125 people). The second group consisted of individuals, whose systolic blood pressure exceeded $130 \mathrm{mmHg}$ at the time of the study and (or) diastolic - $85 \mathrm{mmHg}$ (135 people). Somatotyping technique by Carter and Heath was used. Functional mobility (FMNP) and strength of nervous processes (SNP) were determined using the Diagnost-1 program (Makarenko and Lizogub).

Results. In the individuals with predominance of ecto- and mesomorphic somatotype component, higher levels of major nervous processes were reported in response to strenuous processing of information, which was associated with more advanced mechanisms of information processing, its neurophysiological support. In people with endomorphic somatotype the lower levels of FMNP and SNP were clearly detected that could indicate that the speed characteristics of the nervous processes in them are at a lower level.

Conclusions. In normal blood pressure, the highest indicator of FMNP was found in the individuals with predominance of ecto- and mesomorphic component. In the group with high blood pressure, the indicator at the level below the average was in endomorphs. Predominance of the ectomorphic component tended to increase in the surveyed, and in the mesomorphs was at the average level. The lowest level of SNP was found in the individuals with endomorphic somatotype of both groups.

KEY WORDS: functional mobility of nervous processes; strength of nervous processes; blood pressure; arterial hypertension; somatotype.

\section{Introduction}

In Ukraine, as in the rest of the world, there is an annual increase in the incidence of arterial hypertension $(\mathrm{AH})$, which is particularly alarming about the so-called 'rejuvenation' of this disease. Therefore, the priority direction is prevention of hypertension and early detection of it, as it has been proven that preventive measures carried out at the initial stages of the disease give a significantly greater effect compared with the adult contingent of patients $[1,2]$.

Numerous epidemiological studies have shown that blood pressure (BP) is determined by the influence of both genetic factors and environmental factors. Thus, in $30 \%$ of cases,

\footnotetext{
* Corresponding author: Horban L.I., MD, PhD-student, Department of Physiology with the Basics of Bioethics and Biosafety, I. Horbachevsky Ternopil National Medical University, Ukraine, 2 Slovatskyi Street, Ternopil, 46001, telephone: +380682317579. E-mail: horban@tdmu.edu.ua
}

hypertension is genetically determined, and about $50 \%$ is due to factors of the environment [3].

It is established that the individual-typological features of the central nervous system are treated as highly genetically determined and responsible for the individual peculiarities of the formation, development and occurrence of electrophysiological, psychophysiological, somatic and vegetative functions [4]. The somatotype is also a genetically determined constitutional type. Considering that individuals with different types of constitution are characterized by a certain level of metabolism, which occurs due to the prevailing development of muscle, fat or bone tissue, as well as the presence of psychophysiological differences in them, it is important to study and understand the peculiarities of the course of these processes in the individuals of different somatotypes. Different 
diseases, increased physical activity change the size, contours of the body, but not somatotype [5].

The study of constitutional features is topical matter, since it provides an opportunity to implement an individual approach in assessing the psychophysiological and functional status of a person, allows predicting the peculiarities of the reaction of an organism to external influence [6]. In practical medicine, somatotype is used as an indicator of hereditary predisposition to certain diseases [7], including to arterial hypertension, which is known to be the main factor in population mortality from cardiovascular disease [8].

As each somatotype has certain morphofunctional features of the nervous, endocrine, immune systems activity, as well as the circulatory system, the structure and functions of the internal organs [7], it is especially important to isolate and study these features in the individuals of different somatotypes and with various blood pressure levels.

However, in the literature there is insufficient studies about the individual-typological features of the higher parts of the central nervous system properties in persons with different somatotypes and with various levels of blood pressure that makes the study urgent.

The aim of the research was to study the features of the main individual and typological indicators of higher nervous activity in young people aged 18-22 years old of different somatotype with high and normal blood pressure.

\section{Methods}

Our studies do not contradict the accepted bioethical norms of the Helsinki Declaration adopted by the General Assembly of the World Medical Association on Human Rights (19752000), the International Code of Medical Ethics and the laws of Ukraine and can be used in scientific work (decision of the Bioethics Commission of the I. Horbachevsky Ternopil National Medical University, Protocol No. 54, dated 27.08.2019). The research was conducted in the Psychophysiological Research Laboratory of the Department of Physiology, Bioethics and Biosafety of I. Horbachevsky Ternopil National Medical University, certified by the Ministry of Health of Ukraine (Certificate No. 055/13).

Two groups of young people aged 18-22 years old were involved in the research. The control group (CG) comprised persons, whose blood pressure corresponded to the optimal level according to the WHO classification (125 persons). The second group consisted of individuals, whose systolic blood pressure exceeded $130 \mathrm{mmHg}$ and (or) diastolic $-85 \mathrm{mmHg}$ (135 people) at the time of study. Blood pressure was measured by Korotkov's method after resting for 5 minutes. The average result was recorded after measuring three times [9].

The somatotype of the subjects was determined using the Carter and Heath technique of somatotyping [10]. The somatotype is defined as a quantitative assessment of the present form and composition of the human body. The authors identified three constituent components: endomorphy, mesomorphy and ectomorphy. Endomorphy reflects the fat content of a human body, mesomorphy characterizes development of the skeleton and skeletal muscles, and ectomorphy demonstrates the harmony of the body and the extent of its elongation. The advantage of this scheme is the possibility of an objective assessment of each constitution component by the suggested formulas. When characterizing a somatotype, the predominant component is placed in the second place, and the next, larger, at the first.

To determine the basic individual-typological indicators of higher nervous activity - functional mobility (FMNP) and strength of nervous processes (SNP), the Diagnost-1 computer program by Makarenko and Lizogub [4], was used. As a mental load for processing of information, subject symbols (geometric figures) were used in the 'feedback mode'. When performing a test task in this mode, the signal exposure varied automatically depending on the nature of the answers: after the correct answer, the next signal exposure reduced by $20 \mathrm{~ms}$, and after the wrong one, on the contrary, it extended to the same level. The range of signal exposure oscillation during operation was within $20-900 \mathrm{~ms}$. Before performing the task the examined person was offered the following instruction: on presentation of the square figure as soon as possible press and release the right hand right button of the transition device, on the figure of the circle - left hand left button, and on the figure triangle none of the buttons to push (this is a brake irritant). An indicator of the maximum speed of information processing, which evaluated the property of the functional mobility of the nervous processes in this mode, according to the method, was the time of execution of the fixed load -120 signals. The faster the subject performed the test, the higher his level of functional mobility was. The test was performed three times with 120 stimuli (geo- 
metric shapes) and was evaluated for the best result. Triple testing was performed because the most optimal and stable value of the speed of information processing is achieved during the first three attempts. Based on this, Makarenko suggested the following graduation of FMNP levels in terms of task time: high - 57 and less than, higher than average - 57.1-63.5 $\mathrm{s}$, average - 63.6-73.7 s, lower than average - 73.8$79.9 \mathrm{~s}$, low -87.0 and above. The determination of the strength of the nervous processes was carried out after the definition of the FMNP. The measure of the level of strength was the total number of reported and processed signals surveyed within 5 minutes. To evaluate the SNP, we used the level scale according to the revised number of signals developed by Makarenko: high level -740 and more stimuli, higher than average - 739-691 stimuli, average - 690-630 stimuli, lower than average - 629-581 stimuli, low - 530 and and less.

The results of the study were statistically processed using a licensed statistical software package Analyst Soft Stat plus 6. The probability was estimated using the one-way ANOVA analysis based on the Tukey criterion. To compare the statistical significance of differences in the results between the groups, the method of a posterior comparison was used with an unequal number of observations. To verify the normal distribution of results, the Kolmogorov-Smirnov and Lilliefors criteria [11-13] were used.

\section{Results}

By the somatotyping method, six mixed somatotypes among all the examined ones were identified: mesomorphic endomorph, mesomorphic ectomorph, endomorphic mesomorph, ectomorphic endomorph, endomorphic ectomorph, ectomorphic mesomorph.

Functional mobility of nervous processes is characterized by the maximum rate of errorfree mental load processing with the differentiation of positive and inhibitory signals [4].

According to the results of the functional mobility of the nervous processes definition in the group of subjects with normal blood pressure, high level was established in endomorphic mesomorphs and endomorphic ectomorphs. The largest number of the subjects surveyed with the level of the FMNP above the average was registered in the mesomorphic ectomorphs, and with a level below the average - in the mesomorphic endomorphs. In mesomorphic endomorphs and ectomorphic mesomorphs, the average level, which was observed in more than half of the subjects, was also prevalent, and the average level of FMNP was observed in almost all ectomorphic endomorphs. The low level of FMNP was not found in any of this group subjects (Fig. 1).

Functional mobility of nervous processes in individuals of different somatotypes with high blood pressure was lower compare to that of CG. The low level of FMNP was revealed in half of the individuals with domination of the endomorphic component of the somatotype (mesomorphic and ectomorphic endomorphs). Lower than average level was found among the endomorphic mesomorphs, meso- and ectomorphic endomorphs and amounted to about one third of the examined somatotypes. The average

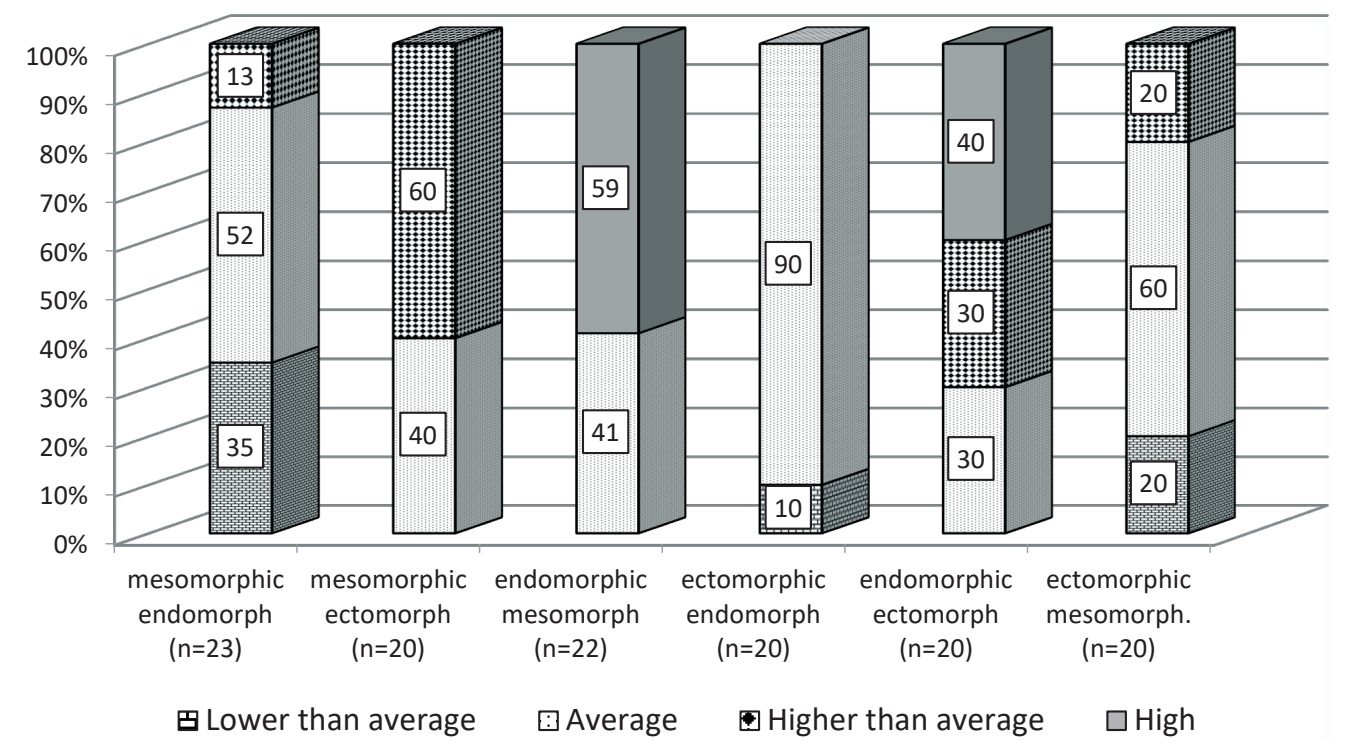

Fig. 1. Distribution of functional mobility of nerve processes levels in the persons of control group, \%. 
level of functional mobility predominated among endomorphic meso- and ectomorphs, and the higher than average level was observed only in individuals of ectomorphic somatotype and ectomorphic mesomorphs. The functional mobility of the nerve processes at a high level was found only in mesomorphic ectomorphs and ectomorphic mesomorphs (about 30\% of the surveyed) (Fig. 2).

The strength of the nervous processes characterizes the capacity of the brain cells and manifests itself in their ability to withstand long-term concentrated excitation or the effect of short but very strong stimuli in a high tempo [4]. Therefore, a large amount of processed information indicates a higher level of SNP, and the lower one - on the reduction of brain function, and therefore the strength of the nervous processes and is characterized by a smaller amount of load performed [14]. The analysis of the attained data proved that the strength of the nervous processes in the persons of the CG at a high level was only in the small part of the endomorphic ectomorphs and ectomorphic mesomorphs, and higher than average level of SNP was observed only in them. The average SNP level was found among all somatotypes of CG, however, the largest number of individuals was among endomorphic mesomorphs and mesomorphic ectomorphs. One third of individuals from mesomorphic endomorphs and mesomorphic ectomorphs, as well as half of the representatives of ectomorphic endomorphs in the control group, were found to have the strength of the nervous processes at higher than average level. The low level of SNP was only among those with predominance of the endomorphic component in the somatotype (ecto- and mesomorphic endomorphs) (Fig. 3).

In subjects with elevated blood pressure, low levels of nervous processes were detected in all somatotypes, except for endomorphic ectomorphs. The largest number of people with this level of SNP was among ectomorphic endomorphs and was about half of the surveyed. The level below the average among the second group was registered in representatives of all somatotypes, and the largest number of subjects surveyed with this level was observed among individuals with predominance of the endomorphic component of the somatotype (meso- and ectomorphic endomorphs). The average level of nervous processes strength was recorded in half of the examined somatotypes, except for the endomorphic ectomorphs, in which the average SNP was in the largest number of individuals. The level above the mean was found only in the persons with predominance of the ecto- and mesomorphic component of the somatotype, with the highest percentages of people with this level being in endomorphic mesomorphs, and the smallest in mesomorphic ectomorphs. A high level of nervous processes strength in individuals with high blood pressure was observed only in a small amount of ectomorphic mesomorphs (Fig. 4).

According to the one-way ANOVA analysis results, the statistically significant difference between the indices of FMNP $(p=0.0012)$ between somatotypes within the groups of the subjects under study was established. Using a

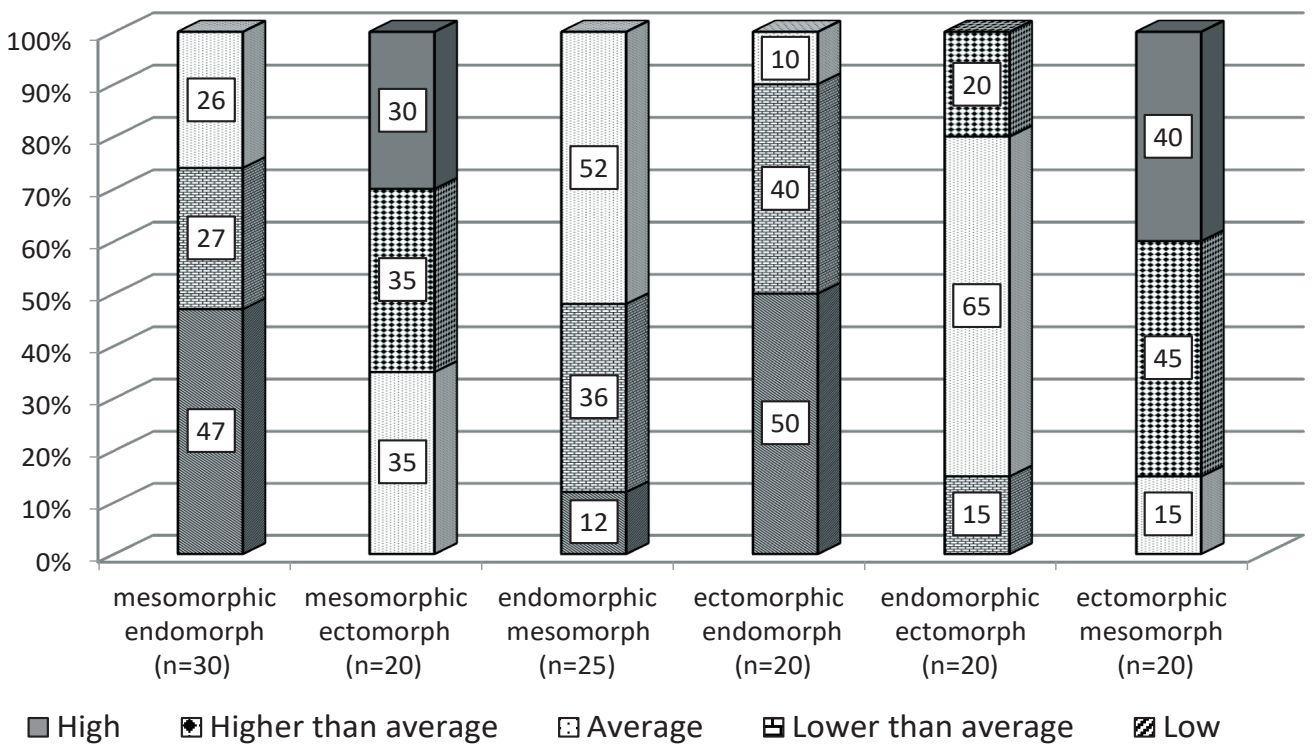

Fig. 2. Distribution of functional mobility of nerve processes levels in people with high blood pressure, \%. 


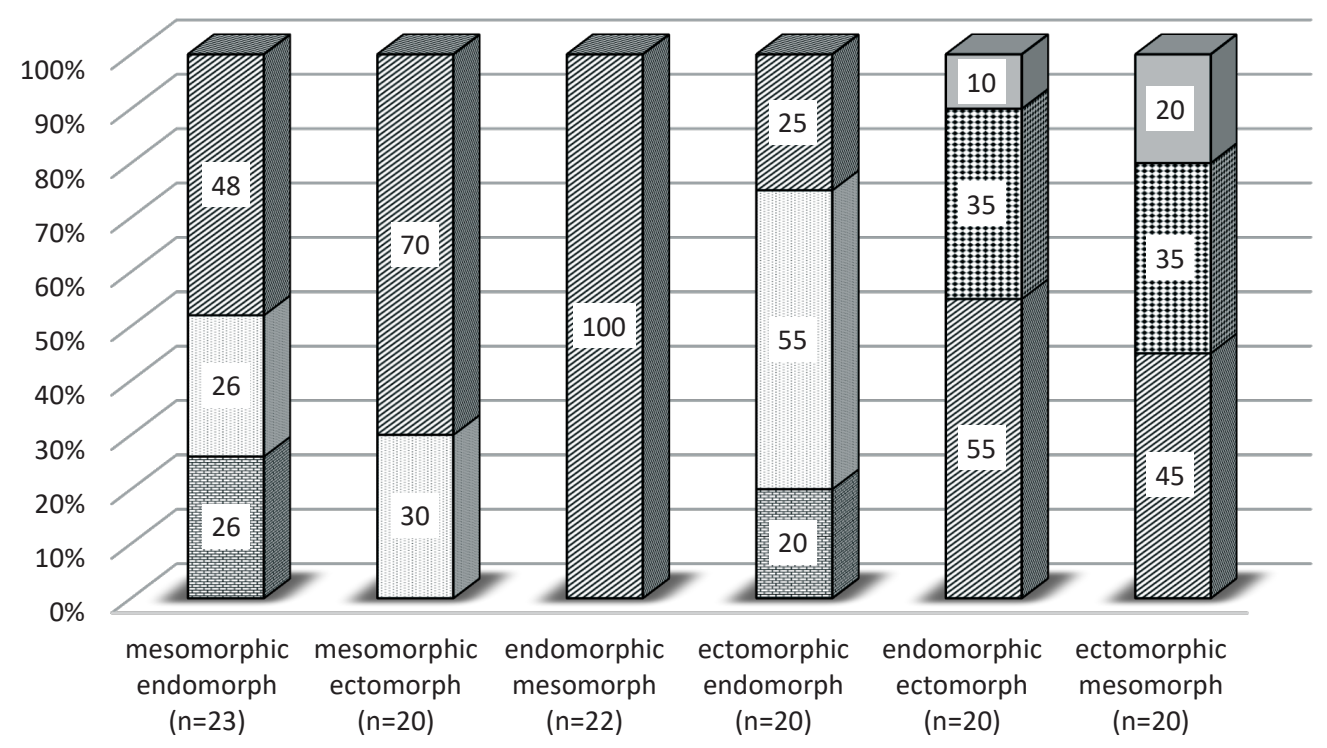

回 Low $\square$ Lower than average $\quad$ Average Higher than average $\square$ High

Fig. 3. Distribution of nervous processes strength levels in the persons of control group, \%.

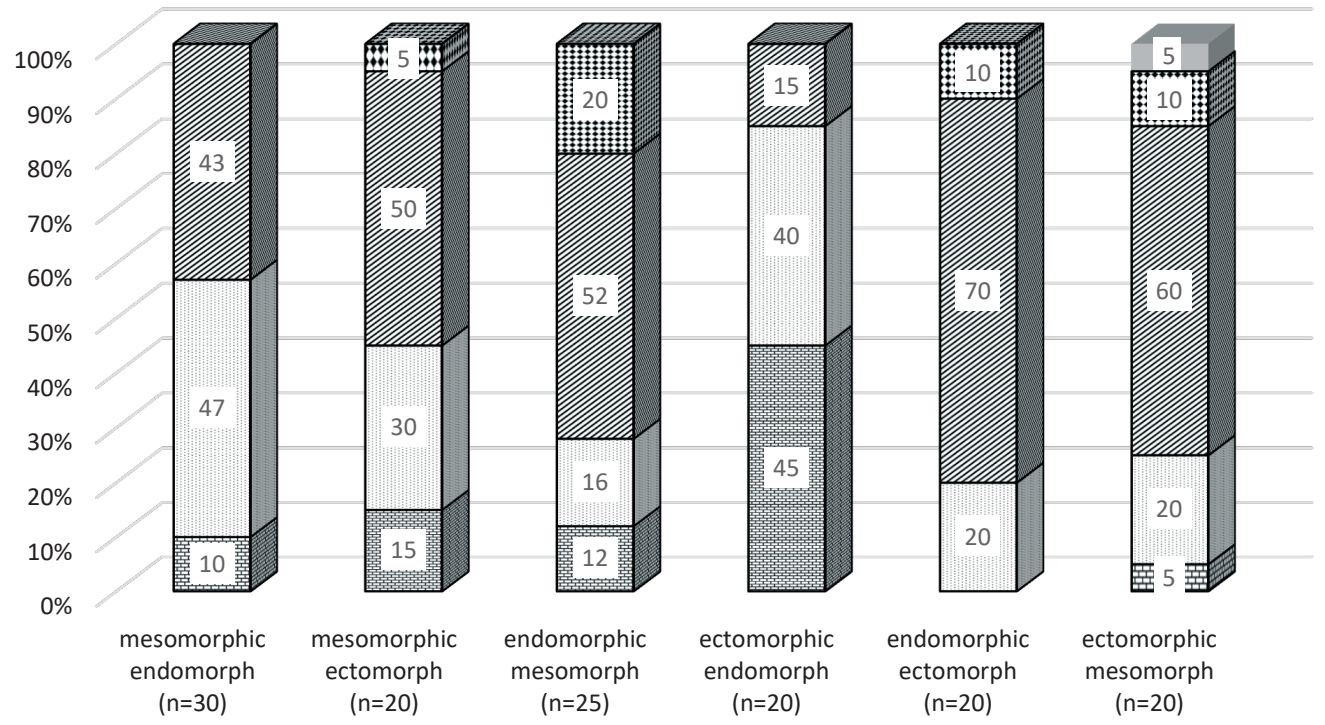

田 Low $\quad$ L Lower than average $\quad$ Higher than average High

Fig. 4. Distribution of nervous processes strength levels in the subjects with high blood pressure, \%.

posteriori comparison method and Tukey's criterion, the differences between somatotypes were determined by the FMNP within the groups with normal and elevated BP in the case of an unequal number of observations. In the examined CG, the difference between the indicators of functional mobility of the nervous processes was established between the mesomorphic endomorphs, in which the time of information processing was significantly longer compared to endomorphic mesomorphs $(p=0.0001)$ and mesomorphic ectomorphs $(p=0.0066)$. Endomorphic meso- and ectomorphs of CG showed a significant difference with ectomorphic mesomorphs $(p=0.0010)$, in which the value of processing time was significantly lower (Table 1).

In people with high blood pressure a reliable difference of FMNP was established between the subjects with the dominated endomorphic component (meso-, ectomorphic endomorphs), in which the mean value of the task execution time was higher compared to those with predominance of the ectomorphic component of the somatotype $(p=0.0006)$, as well as with ectomorphic mesomorphs $(p=0.0002)$. The FMNP of mesomorphic ectomorphs and ectomorphic mesomorphs 
Table 1. Parameters of FMNP in the individuals of different somatotype with normal and high blood pressure

\begin{tabular}{|l|c|c|c|c|}
\hline \multirow{2}{*}{\multicolumn{2}{c}{ Somatotype }} & \multicolumn{4}{|c|}{ Functional mobility of nervous processes } \\
\cline { 2 - 5 } & \multicolumn{2}{|c|}{$\begin{array}{c}\text { Subjects with normal blood } \\
\text { pressure }\end{array}$} & \multicolumn{2}{c|}{$\begin{array}{c}\text { Subjects with elevated blood } \\
\text { pressure }\end{array}$} \\
\cline { 2 - 5 } & $\mathrm{n}$ & $\mathrm{M} \pm \mathrm{m}, \mathrm{sec}$ & $\mathrm{n}$ & $\mathrm{M} \pm \mathrm{m}, \mathrm{sec}$ \\
\hline Mesomorphic endomorphs & 23 & $73.67 \pm 1.31$ & 30 & $78.11 \pm 0.94$ \\
\hline Mesomorphic ectomorphs & 20 & $59.34 \pm 1.81$ & 20 & $60.93 \pm 1.34$ \\
\hline Endomorphic mesomorphs & 22 & $69.89 \pm 0.94$ & 25 & $74.14 \pm 0.97$ \\
\hline Ectomorphic endomorphs & 20 & $66.12 \pm 0.82$ & 20 & $79.49 \pm 1.08$ \\
\hline Endomorphic ectomorphs & 20 & $66.63 \pm 0.61$ & 20 & $68.50 \pm 1.18$ \\
\hline Ectomorphic mesomorphs & 20 & $59.35 \pm 0.42$ & 20 & $58.33 \pm 1.02$ \\
\hline
\end{tabular}

Note. The statistical significance between the groups of the examined somatotypes and the rate of blood pressure is presented in the text.

with elevated blood pressure was significantly higher compared to those with an endomorphic component predominating in the somatotype $(p=0.0006)$, endomorphic mesomorphs $(p=0.0002)$, and endomorphic ectomorphs $(p=0.0002)$. The reliable difference between FMNP in ectomorphic endomorphs of CG was established with ectomorphic endomorphs of the group of high blood pressure $(p=0.0018)$ (Table 1).

According to the one-way ANOVA analysis results, the probable difference between the SNP indices $(p=0.0036)$ was established among somatotypes within the groups of the subjects under study. Using a posteriori comparisons method and the Tukey's criterion, differences in groups with normal and elevated blood pressure were determined in the case of an unequal number of observations on the SNP. In the examined CG, a statistically significant difference in the strength of the nervous processes was established between mesomorphic endomorphs and endomorphic ectomorphs $(p=0.0020)$. The number of transformed signals within 5 minutes among mesomorphic ectomorphs and endomorphic mesomorphs was significantly higher than ectomorphic endomorphs ( $p=0.0236)$. The examined ectomorphic endomorphs had a lower level of the nervous processes strength compared with those with a dominant ectomorphic component of the somatotype $(p=0.0236)$ and with endomorphic mesomorphs $(p=0.0342)$. The average indicator of the number of processed signals in endomorphic mesomorphs was higher and statistically different from that in the subjects with the dominant endomorphic component of somatotype $(p=0.002)$ (Table 2$)$.

In the group with high blood pressure, mesomorphic endomorphs had a significantly lower SNP compared with endomorphic ectomorphs $(p=0.0311)$ and the individuals with a dominant mesomorphic component in the somatotype $(p=0.0227)$. Endo- and ectomorphic mesomorphs had a higher level of nervous processes strength than those with domination of the endomorphic component $(p=0.0427)$. SNP in ectomorphic endomorphs was signi-

Table 2. Parameters of SNP in the individuals of different somatotype with normal and high blood pressure

\begin{tabular}{|l|c|c|c|c|}
\hline \multirow{2}{*}{\multicolumn{2}{c}{ Somatotype }} & \multicolumn{4}{c|}{\begin{tabular}{c} 
Strength of the nervous processes \\
\cline { 2 - 5 }
\end{tabular}} & \multicolumn{2}{|c|}{$\begin{array}{c}\text { Subjects with normal blood } \\
\text { pressure }\end{array}$} & \multicolumn{2}{c|}{$\begin{array}{c}\text { Subjects with elevated blood } \\
\text { pressure }\end{array}$} \\
\cline { 2 - 5 } & $\mathrm{n}$ & $\mathrm{M} \pm \mathrm{m}$ & $\mathrm{n}$ & $\mathrm{M} \pm \mathrm{m}$ \\
\hline Mesomorphic endomorphs & 23 & $618.35 \pm 9.14$ & 30 & $614.03 \pm 5.05$ \\
\hline Mesomorphic ectomorphs & 20 & $650.40 \pm 11.70$ & 20 & $631.95 \pm 9.54$ \\
\hline Endomorphic mesomorphs & 22 & $681.27 \pm 5.59$ & 25 & $644.88 \pm 9.68$ \\
\hline Ectomorphic endomorphs & 20 & $614.00 \pm 6.45$ & 20 & $589.70 \pm 7.41$ \\
\hline Endomorphic ectomorphs & 20 & $679.55 \pm 9.56$ & 20 & $649.80 \pm 5.87$ \\
\hline Ectomorphic mesomorphs & 20 & $659.75 \pm 11.30$ & 20 & $651.00 \pm 9.57$ \\
\hline
\end{tabular}

Note. The statistical significance between the groups of the examined somatotypes and the rate of blood pressure is presented in the text. 
ficantly lower than those surveyed, in whom the somatotype was dominated by ectomorphic and mesomorphic components $(p=0.0326)$ (Table 2).

\section{Discussion}

It is established that the individual-typological properties of higher nervous activity are the basis for formation of sensomotoric, autonomic and mental functions of the human body in different conditions [14]. Genetic origin of strength and functional mobility of the nervous processes parameters determines the effectiveness of any activity, especially cognitive, as well as the effectiveness of information processing of [15]. We have found that these parameters determine the functional state of the nervous system and have certain features in people of different somatotypes. In particular, in the surveyed individuals with a predominance of the ecto- and mesomorphic component of somatotype, in response to the intense work on information processing, higher levels of properties of the main nervous processes (FMNP and SNP) were recorded, which is possibly due to more advanced mechanisms for processing and evaluation of information, its neurophysiological and autonomous support.

By the nature of the data obtained, the representatives of the endomorphic somatotype clearly show presence of lower levels of the basic individual-typological characteristics of higher nervous activity that may indicate that the rapid characteristics of the course of nervous processes in the cerebral cortex are lower in them and the time of the central processing of information is longer. Regarding the state of higher nervous activity in young people with normal and high blood pressure, the level of the FMNP clearly distinguishes between persons with prevalence or presence of an endomorphic component in a somatotype. This examined functional mobility of the nervous processes is registered at a level lower than that of the same somatotypes with normal blood pressure. Such results may be explained by the fact that at increased levels of blood pressure the adaptive mechanisms increase that in turn causes changes in the work of the nervous and cardiovascular system.

Differences in the individual-typological properties of higher nervous activity in the individuals of different somatotypes can be a foundation for the successful training, obtaining labor and sports skills and using them in practical activities and can be basic in the systems of professional psychophysiological selection.

\section{Conclusions}

The analysis of the results of the level of functional mobility and the strength of the nervous processes in young people of different somatotypes showed that among the subjects with normal blood pressure, the highest index of FMNP was in people with predominance of ecto- and mesomorphic (mesomorphic ectomorphs, endomorphic ectomorphs, endomorphic mesomorphs, ectomorphic mesomorphs) component of the somatotype that could indicate a higher level of complex information processing than in the individuals of these somatotypes compared with the endomorphic component (mesomorphic endomorphs, ectomorphic endomorphs) of the somatotype. The functional mobility of the nervous processes in the group with high blood pressure was registered at lower than average level in the endomorphs, while in the surveyed with the predominance of the ectomorphic component, the index tended to increase, and the mesomorphs were on average level. The strength of the nervous processes did not differ among the individuals of different somatotypes with normal and elevated blood pressure.

The lowest level of the nervous processes strength was found among the individuals of the somatotype with domination of the endomorphic (mesomorphic endomorphs, ectomorphic endomorphs) component in both groups. This may indicate that in persons with these somatotypes, the ability to endure long-term and concentrated excitation or the action of a strong but short-term stimulus is slightly lower than that of other somatotypes without passing over to the supramental inhibition.

\section{Funding}

This research received no external funding.

\section{Conflict of Interests}

The authors declare no conflict of interest.

\section{Authors Contributions}

Vadzyuk S. N. - conceptualization, project administration, supervision, writing - review \& editing; Horban L. I. - conceptualization, data cu ration, formal analysis, investigation, methodology, project administration, visualization, writing - original draft; Papinko I. Ya. - conceptualization, project administration, supervision, writing - review \& editing. 


\title{
ОЦІНКА ОСНОВНИХ ІНДИВІДУАЛЬНО-ТИПОЛОГІЧНИХ ПОКАЗНИКІВ ВИЩОЇ НЕРВОВОЇ ДІЯЛЬНОСТІ В МОЛОДИХ ОСІБ РІЗНОГО СОМАТОТИПУ 3 НОРМАЛЬНИМ ТА ПІДВИЩЕНИМ АРТЕРІАЛЬНИМ ТИСКОМ
}

\author{
С. Н. Вадзюк, Л. І. Горбань, І. Я.Папінко \\ ТЕРНОПІЛЬСЬКИЙ НАЦІОНАЛЬНИЙ МЕДИЧНИЙ УНІВЕРСИТЕТ IМЕНІ І. Я. ГОРБАЧЕВСЬКОГО, \\ ТЕРНОПІЛЬ, УКРАЇНА
}

Вступ. Індивідуально-типологічні особливості чентральної нервової системи трактуються як високо генетично детерміновані. Кожному соматотипу властиві характерні морфофункціональні особливості діяльності різних системи, в тому числі системи кровообігу, тому актуальним є вивчення їх в представників різних соматотипів та рівнем артеріального тиску (AT).

Мета роботи: вивчити особливості основних індивідуально-типологічних показників вищої нервовоі діяльності в осіб різного соматотипу з нормальним та підвищеним $A T$.

Методи. Відібрано контрольну групу (КГ) осіб, в яких величина АТ відповідала оптимальному рівню за класифікацією ВООЗ (125 осіб). Другу групу склали особи, у яких на момент дослідження систолічний АТ перевищував 130 мм рт. cm. і (або) діастолічний - 85 мм рт. cm. (135 осіб). Техніка соматотипування за Carter i Hеath. Визначення функціональної рухливості (ФРНП) та сили нервових процесів (СНП) за допомогою програми «Діагност-1» (Макаренко та Лизогуб).

Результати. В осіб з переважанням екто- та мезоморфної складової соматотипу у відповідь на напружену роботу з переробки інформації зареєстровані вищі рівні основних нервових процесів, що пов'язано із більш досконалими механізмами переробки інформачії, ії нейрофізіологічного забезпечення. У людей ендоморфного соматотипу чітко простежуються наявність нижчих рівнів ФРНП та СНП, що може свідчити про те, що швидкісні характеристики перебігу нервових процесів в них знаходяться на нижчому рівні.

Висновки. В осіб з нормальним артеріальним тиском найвищим показник ФРнП був в осіб з переважанням екто- та мезоморфного компоненту. У групі з підвищеним артеріальним тиском показник на рівні нижче середнього був в ендоморфів, в обстежених із переважанням ектоморфного компоненту мав тенденцію до зростання, а в мезоморфів перебував на середньому рівні. Найнижчий рівень СНП виявлений в осіб ендоморфного соматотипу серед обох груп.

КЛЮЧОВІ СЛОВА: функціональна рухливість нервових процесів; сила нервових процесів; артеріальний тиск; артеріальна гіпертензія; соматотип.

\section{Відомості про авторів}

Вадзюк Степан Несторович, д-р мед. наук, професор, заслужений діяч науки і техніки України, завідувач кафедри фізіології з основами біоетики та біобезпеки, Тернопільський національний медичний університет імені І. Я. Горбачевського, Україна.

Горбань Людмила Ігорівна, аспірант кафедри фізіології з основами біоетики та біобезпеки, Тернопільський національний медичний університет імені I. Я. Горбачевського, Україна.

Папінко Ігор Ярославович, канд. мед. наук, доцент, кафедра фізіології з основами біоетики та біобезпеки, Тернопільський національний медичний університет імені І. Я. Горбачевського, Україна.

Information about the authors

Vadzyuk S. N., MD, Ph.D., DSc, Professor, Head of the Department of Physiology with the Basics of Bioethics and Biosafety, I. Horbachevsky Ternopil National Medical University, Ukraine.

ORCID 0000-0001-9105-8205, e-mail: vadzyuk@tdmu.edu.ua

Papinko I. Ya., MD, Ph.D., Associate Professor, Department of Physiology with the Basics of Bioethics and Biosafety, I. Horbachevsky Ternopil National Medical University, Ukraine.

ORCID 0000-0001-6129-0097, e-mail: papinko@tdmu.edu.ua

Horban L. I., MD, PhD-student, Department of physiology with the Basics of Bioethics and Biosafety, I. Horbachevsky Ternopil National Medical University, Ukraine.

ORCID 0000-0002-8572-239X 46001, e-mail: horban@tdmu.edu.ua 


\section{References}

1. Grebla RC, Rodriguez CJ, Borrell LN, Pickering TG. Prevalence and determinants of isolated systolic hypertension among young adults: the 1999-2004 US National Health And Nutrition Examination Survey. Journal of hypertension. 2010 Jan;28(1):15-23.

doi: 10.1097/HJH.0b013e328331b7ff

2. Matyukha LF, Orlovskaya HB, Mayatskaya OV. Arterial hypertension in children and adolescents: risk factors, diagnostic aspects and the basis of prevention. 2015;6(62):131-5.

3. Pashkova YuP, Palagnyuk GO, Ruzhansky VO, Zhebel VM, Zhebel NP. A new look at dermatoglyphics - as a method of diagnosing hypertension. Bukovinsky medical bulletin. 2015;3(75):237-9.

4. Makarenko NV, Lizohub VS. Bezkopilny. OP (2014). Methodical instructions for the practice of differential psychophysiology and physiology of higher human nervous activity. 102.

5. Kutserib T, Grinkov M, Vovkanych L, Musika F. Features of the somatotype of the representatives of the game types of sport. Physical activity, health and sports. 2015;4(18):37-44.

6 . Voloshin OS. Assessment of physical development and features of the course of nervous processes in persons of different constitutional type of adolescence. Scientific notes of Ternopil National Pedagogical University named after Volodymyr Hnatyuk Biology.2018;2(73):192-6.

7. Sidorchenko KM. Taking into account the somatotype of pupils when correcting their health in the process of physical education. Pedagogy, psychology, medical and biological problems of physical education and sports. 2010;8:77-9.
8. Whelton PK, Carey RM. Guideline for the prevention, detection, evaluation, and management of high blood pressure in adults: a report of the American College of Cardiology/ American Heart Association task force on clinical practice guidelines. Hypertension. 2017;71(6):283.

9. Svischenko EP, Bagriy AE, Yena LM. Recommendations of the Ukrainian Association of Cardiology for the prevention and treatment of arterial hypertension. Kyiv: PE VMB; 2008:72.

10. Carter JE. The Heath-Carter anthropometric somatotype-Instruction Manual. Surrey, Canada: TeP and Rosscraft.

11. Bakhrushin WE. Methods of data analysis: a manual for students. Zaporozhye: CPU. 2011:81-90.

12. Grzhibovsky AM, Ungureanu TN. Singlefactor dispersion analysis using STATA software package. Ecology of a person. 2014;5:60-4.

13. Grzhibovsky AM. Analysis of three and the pain of independent groups of quantitative data. Ecology of a person. 2008;3(1):50-8.

14. Makarenko MV, Lyzozhub VS, Maluga VM, Panchenko VM. Sensomotoric reactivate under the conditions of performing complex mental loads on the processing of visual-auditory information in people with different individualtypological properties of the higher parts of the central nervous system. Bulletin of the National Defense University of Ukraine. 2013;1(32): 229-35.

15. Kozhemyako TV. Individual neurophysiological and vegetative mechanisms of information processing of individuals with various functional mobility of nervous processes. Cherkasy University Bulletin: Biological Sciences Series. 2017 May 30(1):24-31.

Received 03 September 2019; revised 04 October 2019; accepted 23 October 2019.

This is open access article distributed under the Creative Commons Attribution License, which permits unrestricted use, distribution, and reproduction in any medium, provided the original work is properly cited. 